\title{
Volume Change and Cracks Behavior of Lime Treated Expansive Soils
}

\author{
Abdulrahman Aldaood ${ }^{1}$, Amina Khalil2, Ibrahim Alkiki³, Madyan Alsaffar ${ }^{4}$ \\ Civil Department, College of Engineering, Mosul University, Mosul, Iraq
}

\begin{abstract}
This research work study the influence of cyclic wetting and drying on free swell potential of untreated and lime treated expansive clayey soils. Such a study is required to understand the behavior of these soils during wet-dry cycles. Two expansive soils (a polwhite bentonite and a kaolinite) with different plasticity indexes were used in this study. The soil samples were treated with different lime content in the order of $(3,5$ and $7 \%$ by the dry weight of soil). The lime treated soil samples were cured at $20^{\circ} \mathrm{C}$ for 28 and 180 days. The untreated and lime treated soil samples were subjected to four wet-dry cycles. Free swell potential and cracks propagation were studied during lime addition and wet-dry cycles. Results showed that, the free swell potential of untreated soil samples; in general; decreased with increasing wet-dry cycles, and all of the soil samples reached equilibrium after the second cycle. While the cracks propagation increased with these cycles, especially of bentonite soil samples. Larger cracks propagation has been observed in the bentonite soil samples. Lime addition enhanced the free swell potential values of the two expansive soils and there was a drastic decrease in free swelling potential and cracks propagation of these soils. The beneficial effect of lime treatment to control the swelling values was partly lost by the first wet-dry cycles, and the free swell potential increased at the subsequent cycles.
\end{abstract}

KEYWORDS : Expansive soil, lime treatment, wet-dry cycles, swell potential, cracks.

\section{INTRODUCTION}

lightly loaded engineering structures like roads, railways, channels or reservoir linings. The two main principal concerns related to the expansive soils are swelling and shrinkage of clays and change in materials properties under a range of moisture content variations (Day, 1994; Basma et al., 1996). It is clearly evident that the swell-shrink or wet-dry cycles can change the clay structure in the soil leading to changes in soil behavior and causing some difficulties in engineering application (Kodikara et al., 1999). Lowvolume roads constructed on clay subgrades are a particular challenge to the geotechnical engineers because the volumetric changes cause instability of the road, resulting in an uneven pavement surface,

Academic Journal of Nawroz University

(AJNU) Volume 7, No 4 (2018).

Regular research paper : Published 21 December 2018

Corresponding author's e-mail : alzubydi.1979@gmail.com

Copyright $\odot 2017$ Abdulrahman ALDAOOD 1 , Amina

KHALIL $^{2}$, Ibrahim ALKIKI ${ }^{3}$, Madyan ALSAFFAR ${ }^{4}$

This is an open access article distributed under the Creative

Commons Attribution License. detrimental cracking and ultimately premature deterioration and replacement. Swelling behavior of compacted cohesive soils depends on several factors such as: type and amount of clay mineral, moisture content, dry density and soil structure (Dasog et al., 1988; Abdullah et al., 1999). The upward and downward movement (volume change) which occurs to the soil sample during wet-dry cycles, leads to cracks formation. Soil cracks are the result of shrinkage and the low tensile strength. When there is water loss, suction forces increase until the tensile stress is equal to the cohesion forces, then cracks will be occur. Soil improvement methods, for instance, stabilization by chemical additives have been generally applied to solve swelling problems. Lime stabilization is a common method in practice among the others because of its effectiveness and economic usage (Bell, 1996; Afes and Didier, 2000; Al-Rawas et al., 2005; Alper et al., 2006; Akcanca and Aytekin, 2012; Al-Mukhtar et al., 2014). The addition of lime to clay soil induces two chemical reactions: short-term reactions and a longterm reaction (Ingles and Metcalf, 1973). The short-term reactions represented by cation exchange and flocculation, while the long-term reaction represented by pozzolanic reaction. The lime-clay reactions depend 
on several factors, such as the mineralogical composition of the clay soil, the quantity of lime employed for treatment, the moisture content of the soil, the curing time and temperature (Al-Mukhtar et al., 2010; Al-Mukhtar et al., 2012). Many researchers have investigated the volume change (swell-shrink) of lime treated expansive soils. Rao et al. (2001) showed that, cyclic wetting and drying causes the soils treated by lime to become more porous and the swelling increased with increasing these cycles. Zhang and Cao (2002) presented the effect of lime and fly ash addition on reducing the swelling percent of an expansive soil. It was found that the lime addition reduced the swelling percent of expansive soil and change the soil texture to behave as cohesion-less soil. The impact of cyclic wetting and drying on swelling behavior of clayey soils treated by lime has been investigated by (Guney et al., 2007). The test results showed that the initial benefits of lime stabilization were lost after the first cycle and the swelling potential was increased at the subsequent cycles. An experimental investigation was undertaken to evaluate the swelling behavior and cracks propagation of two expansive soils. Lime was added in the order of $(3,5$ and $7 \%$ by the dry weight of soil) for the two soils samples. The lime treated soil samples were cured at $20^{\circ} \mathrm{C}$ for 28 and 180 days. The untreated and lime treated soil samples were subjected to four wet-dry cycles.

\section{MATERIALS AND TESTING METHODS}

\subsection{Materials}

Two expansive clayey soils were used in this study: a polwhite bentonite and a kaolinite. The composition of the materials was established using mineralogical analysis by X-ray diffraction and atomic emission spectroscopy. The results of these tests showed that the bentonite is composed of $85 \%$ smectite, $10 \%$ feldspaths and $5 \%$ cristobalite, and the kaolinite of $90 \%$ kaolinite and $9 \%$ muscovite (Table 1 ). Bentonite is a very plastic, expansive clay with a plasticity index $(\mathrm{PI})=162 \%$ while kaolinite has a lower plasticity index (PI $=27.3 \%)$.

The quicklime used in this study, supplied by the French company LHOIST, is a very fine lime that passes hrough an $80 \mu \mathrm{m}$ sieve. The activity of the lime used was 94\% (Al-Mukhtar et al., 2010).

Table (1) : Some physical and index properties of natural soil

\begin{tabular}{|l|l|}
\hline Property & Value \\
\hline Liquid limit (\%) & 29 \\
\hline Plastic limit (\%) & 21 \\
\hline Plasticity index (\%) & 8 \\
\hline $\mathrm{pH}$ & 8.0 \\
\hline Electrical Conductivity $(\mu \mathrm{S} / \mathrm{cm})$ & 400 \\
\hline Natural moisture content in situ (\%) & 18.5 \\
\hline Specific gravity Gs & 2.66 \\
\hline
\end{tabular}

\begin{tabular}{|l|l|l|}
\hline $\begin{array}{l}\text { Standard } \\
\text { Compaction }\end{array}$ & $\begin{array}{l}\text { Max. Dry Density } \\
\left(\mathrm{kN} / \mathrm{m}^{3}\right)\end{array}$ & 17.7 \\
\cline { 2 - 3 } & $\begin{array}{l}\text { Optimum Moisture } \\
\text { Content OMC (\%) }\end{array}$ & 11 \\
\hline \multirow{2}{*}{$\begin{array}{l}\text { Grain Size } \\
\text { Distribution }\end{array}$} & Sand (\%) & 17 \\
\cline { 2 - 3 } & Silt (\%) & 64 \\
\cline { 2 - 3 } & Clay (\%) & CL \\
\hline \multirow{2}{*}{ USCS } & Group Symbol & \multicolumn{2}{|c|}{ Lean } \\
\cline { 2 - 3 } & Group Name & $\begin{array}{l}\text { Sandy } \\
\text { Clay }\end{array}$ \\
\hline $\begin{array}{l}\text { Unconfined } \\
\text { (Mpa) }\end{array}$ & Compressive Strength & 0.19 \\
\hline
\end{tabular}

\subsection{Samples Preparation}

A standard Proctor compaction test (ASTM D-698) was selected in the preparation of soil samples. For untreated soil samples, The required amount of water (represented the optimum moisture content) was added and thoroughly mixed to get a uniform moisture content. It was then stored in sealed bags in order to avoid moisture losses and left at least ( 24 hours) as mellowing time, and to ensure a good homogenization of moisture content. After this curing period, the soil sample was statically compacted inside an Oedometer rings (with a final dimension of $71 \mathrm{~mm}$ in diameter and $20 \mathrm{~mm}$ in height to serve for the swelling test), until it reached the maximum dry unit weight of the natural soil (Table 1). For the lime treated soils, the bentonite and kaolinite soil samples were treated by $(3,5$ and $7 \%$ lime) of the dry weight of soil samples. The soil-lime mixtures were first prepared by thoroughly mixing dry predetermined quantities of soil and lime. Then the required amount of water, corresponding to the optimum moisture content of natural soils, as shown in (Table 1), was added and the samples were remixed to obtain a uniform moisture distribution. The mixture was then placed in plastic bags and left for 1 hour as mellowing time (Little 1995). Following, the same procedure of the untreated soil samples. After compaction, the soil sample was immediately wrapped with paraffin to prevent moisture loss. The samples were left to cure at room temperature $\left(20^{\circ} \mathrm{C}\right)$ for 28 and 180 days as curing period.

\subsection{Swelling Measurement}

To evaluate the free swell potential of the untreated and lime treated soil samples, a free swell test was performed using the standard one-dimensional Oedometer device, in accordance with the ASTM standard (D-4546). At the end of curing period, the compacted soil samples in the Oedometer rings were placed in a consolidation cell between two dried porous stones, and a sensitive dial gauge was fixed on top of the consolidation cell to measure the vertical soil displacement. After calibration with an initial vertical pressure of $2.75 \mathrm{kN} / \mathrm{m}^{2}$ (representing the weight of the 
loading plate which is part of the consolidation cell), an initial reading was taken to estimate the swell potential, following which the soil samples were soaked with tap water and allowed to swell under the vertical pressure $(2.75 \mathrm{kPa})$ at a constant laboratory temperature $\left(25^{\circ} \mathrm{C} \pm 2{ }^{\circ} \mathrm{C}\right)$. Time-swell readings were continuously noted during the process. The final reading of the dial gauge (which represents the highest reading) was used to calculate the free swell potential together with the initial height of the soil samples. The time required to reach the final reading of the dial gauge (the maximum value of vertical displacement) depends on the lime content. Thus, the swell test was continued to (24-48 h) until the dial gauge reading had stabilized.

\subsection{Cyclic Swelling Test}

This test was performed to investigate the evolution of the free swell potential of untreated and lime-treated soil samples (only the soil samples cured for 180 days at $20^{\circ} \mathrm{C}$ ), subjected to wet-dry cycles. All soil samples were subjected to alternate wet-dry cycles in the Oedometer device. After calibration with an initial pressure of $(2.75 \mathrm{kPa})$ and recording of the initial reading to estimate the swell potential, as mentioned in Section 2.3, the soil samples were soaked with tap water and allowed to swell fully over $24 \mathrm{~h}$. After that, the final reading was recorded, then the water was drained from the Oedometer cell and the sample kept in the cell for at least $30 \mathrm{~min}$ at room temperature (25 $\left.{ }^{\circ} \mathrm{C} \pm 2{ }^{\circ} \mathrm{C}\right)$, to keep it safe from any damage. The wetted sample was then extruded from the cell and oven dried for $24 \mathrm{~h}$ at $60{ }^{\circ} \mathrm{C}$. After drying and before starting the next cycle, the soil sample was cooled at room temperature $\left(25^{\circ} \mathrm{C} \pm 2{ }^{\circ} \mathrm{C}\right)$ for $30 \mathrm{~min}$. The soil samples in the consolidation ring were again placed in the Oedometer cell, fixed in the Oedometer device and wetted by allowing them to swell over $24 \mathrm{~h}$. In this test, the untreated and lime-treated soil samples were subjected to four cycles of alternate wetting and drying.

\section{RESULTS AND DISCUSSION}

\subsection{Free Swell Potential}

Figure (1) presented the variation of free swell potential of soil samples treated with different lime contents. Initially, the untreated bentonite exhibited a swell potential of $20 \%$, whereas the untreated kaolinite presented a swell potential of $13.5 \%$, indicating that it is less active than bentonite. For the lime treated soils, the free swell potential of soil samples steadily decreased with increasing lime content. The low values were reached at higher lime content (i.e 10\% lime). The bentonite soil samples had swell potentials of (16.8, $11.9,8.6)$ for $(3 \%, 5 \%$ and $7 \%)$ lime content, which gave

a reduction percent of $(16 \%, 41 \%$ and $57 \%)$, respectively. While the reduction values were $(33 \%$, $55 \%$ and $66 \%$ ) for the kaolinite soil samples treated with $(3 \%, 5 \%$ and $7 \%)$ lime content, respectively.

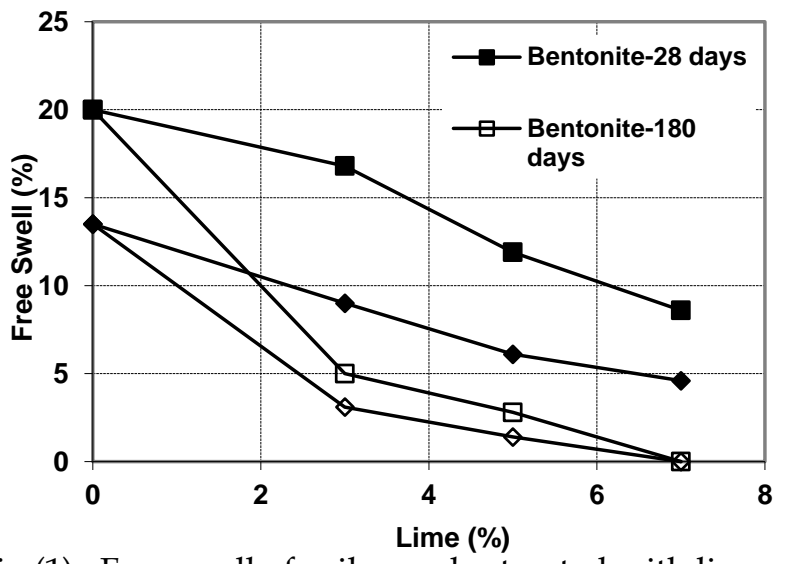

Fig (1) : Free swell of soil samples treated with lime

Figure (2) presented the effect of curing periods on the variations of free swell potential values of bentonite and kaolinite soil samples. The free swell potential of lime treated soil samples decreased with increasing curing periods and a greater reduction was observed for kaolinite as compared with bentonite soils samples. The swell potential was suppressed at 180 days for soil samples treated with $10 \%$ of lime. This reduction is attributed to the addition of lime, which is known to be an effective stabilizer for reducing the swell potential of clay soils. When lime is added to the soil, there is an immediate effect on the soil properties caused by cation exchange, which results in a reduction in the diffuse double layer and soil plasticity, thus causing flocculation and agglomeration. The other reaction is the pozzolanic reaction, which is time-dependent (AlMukhtar et al., 2010; Little, 1995), and which results in cementitious materials such as calcium silicate hydrate $(\mathrm{CSH})$ and calcium aluminates hydrate $(\mathrm{CAH})$ that bind the soil particles together. Thus the magnitude of free swell potential is decreased. 

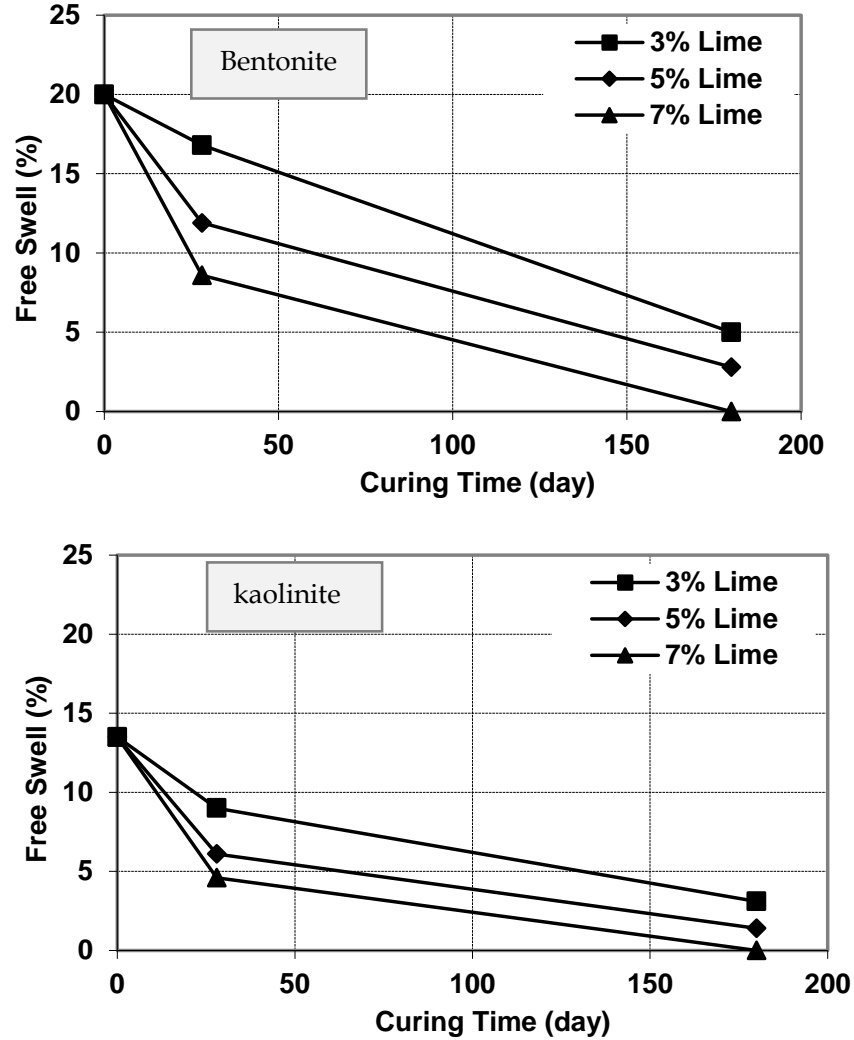

Fig (2) : Relation between curing period and free swell potential

\subsection{Cyclic Free Swell Potential}

Soil in nature is often under conditions of changeable water content and undergoes cyclic wetting-drying. This phenomenon has a marked influence on the properties of soil. The wet-dry cycles test was performed on untreated and only lime-treated soil samples cured for 180 days at $20{ }^{\circ} \mathrm{C}$. Figure (3) illustrated the free swell potential of untreated soil samples corresponding to the number of wet-dry cycles. The free swell potential of bentonite soil samples increased with wet-dry cycles up to the $1^{\text {st }}$ cycle then decreased with increasing these cycles to reach an equilibrium value at the $4^{\text {th }}$ cycle. This behavior is attributed to the difference between the initial water content of soil samples (i.e. the difference between initial water content and the water content at the $1^{\text {st }}$ cycle). While the free swell potential of kaolinite soil samples decreased with increasing wet-dry cycles. The maximum significant reduction in the free swell potential values was recorded after the first cycle and this reduction gradually reached equilibrium as in bentonite soil samples. The reduction in free swell potential values is attributed to destruction of the soil matrix (especially the clay structure matrix) during wet-dry cycles, as well as to partial breakdown of the soil particles by reconstruction of the structure of aggregates that occurred during these cycles (Yazdandoust and Yasrobi, 2010).
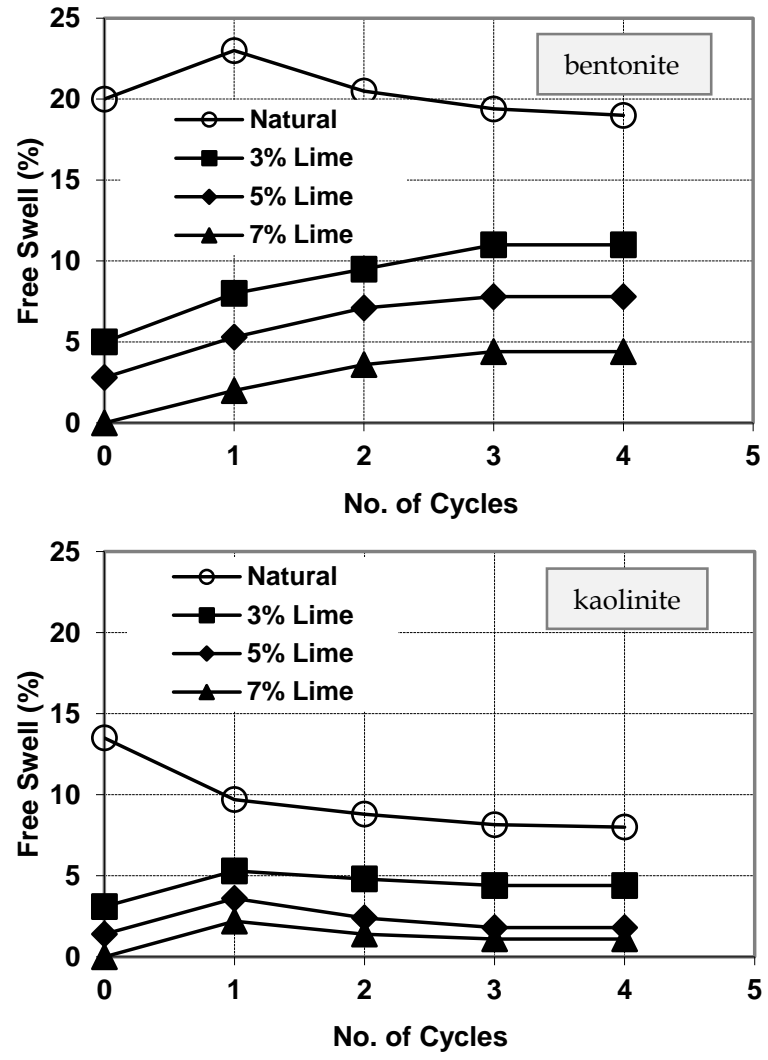

Fig (3) : Free swell potential of soil samples corresponding to the number of wet-dry cycles

The results obtained in this investigation are in agreement with those reported by (Guney et al., 2007). During wet-dry cycles, the bentonite soil samples cracked as a result of shrinkage and low tensile strength, whereas there were no obvious cracks in the kaolinite soil samples, as shown in (figure 4).

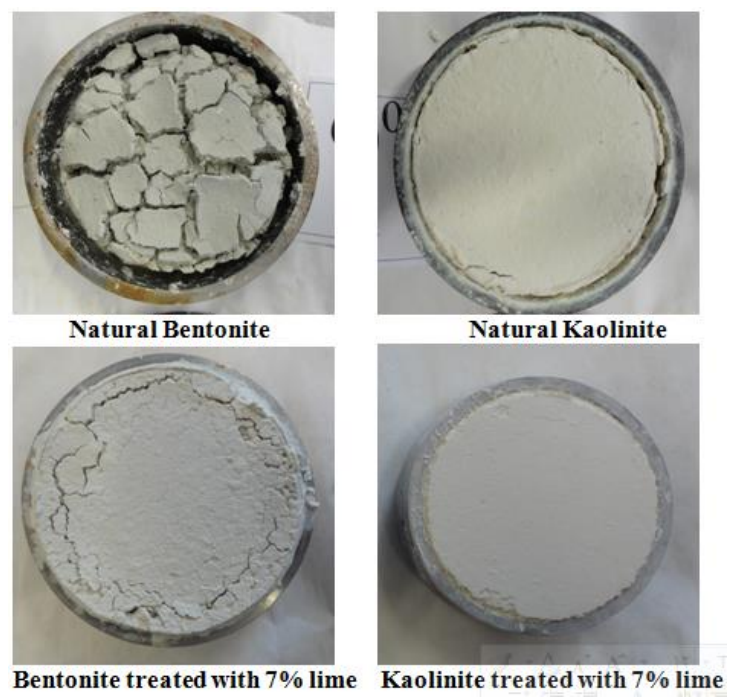

Fig (4) : Cracks propagation in soil samples after 4th wet-dry cycle

Crack propagation occurred when the tensile stress due to the increase in suction (during drying period) was 
equal to or higher than the cohesion forces. These cracks causes a settlement to the expansive soil samples; specially bentonite soil samples; at the beginning of wet cycle as shown in (figure 5). After that the swelling potential increased to reach the desired value corresponding to the number of wet-dry cycle. It worth noting that, the cracks propagation in untreated soil samples; especially the bentonite soil samples; show sign of fatigue after each cycle, so that they exhibit less expansion as compared with un-cycled soil samples. Figure (3) also show that the free swell potential of the lime-treated soil samples increased with increasing number of wet-dry cycles. The maximum free swell potential values were recorded after the second wet-dry cycle. Thereafter, the free swell values reached equilibrium with increasing wetdry cycles. These results support the study carried out by (Khattab et al., 2007).
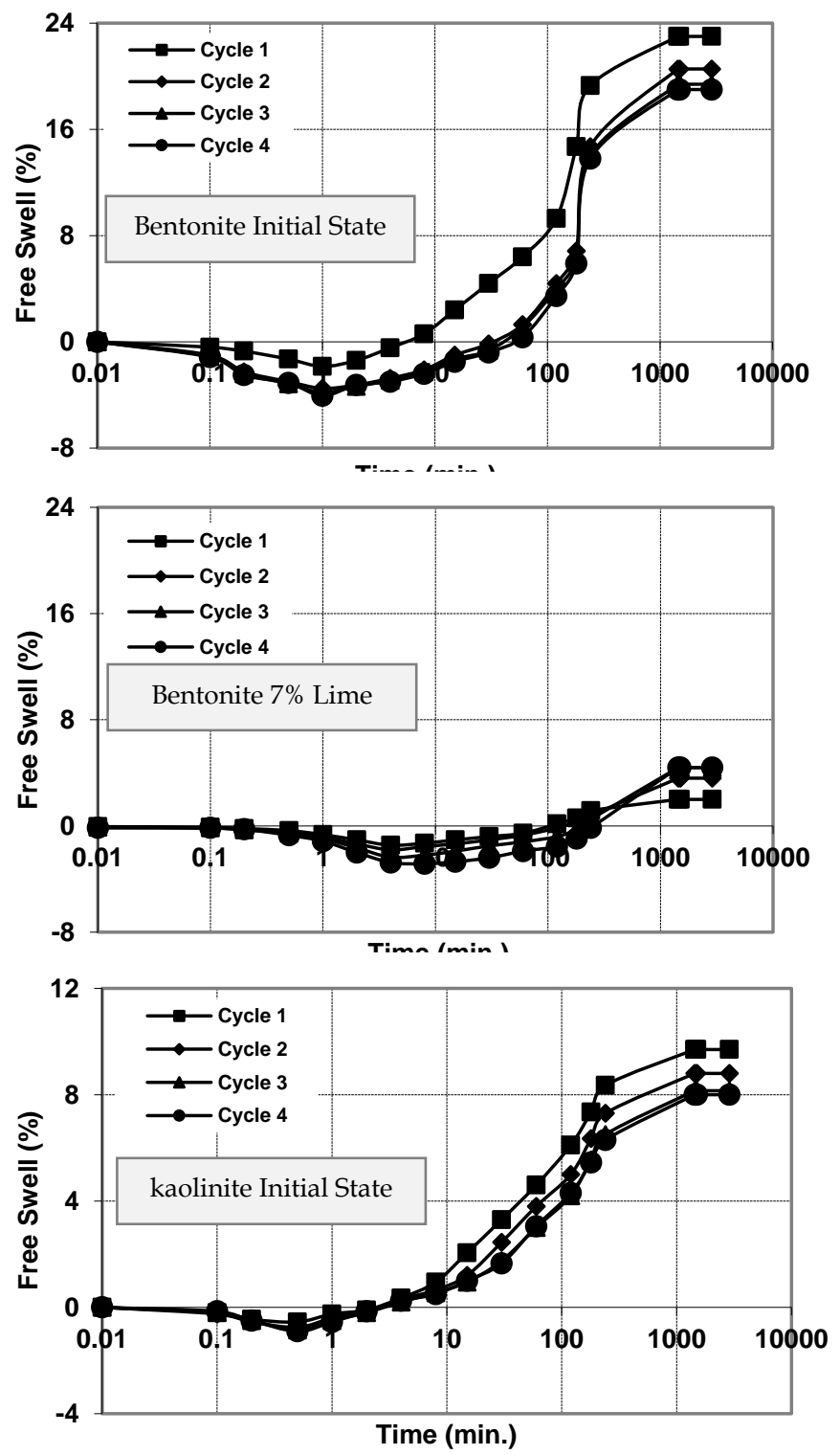

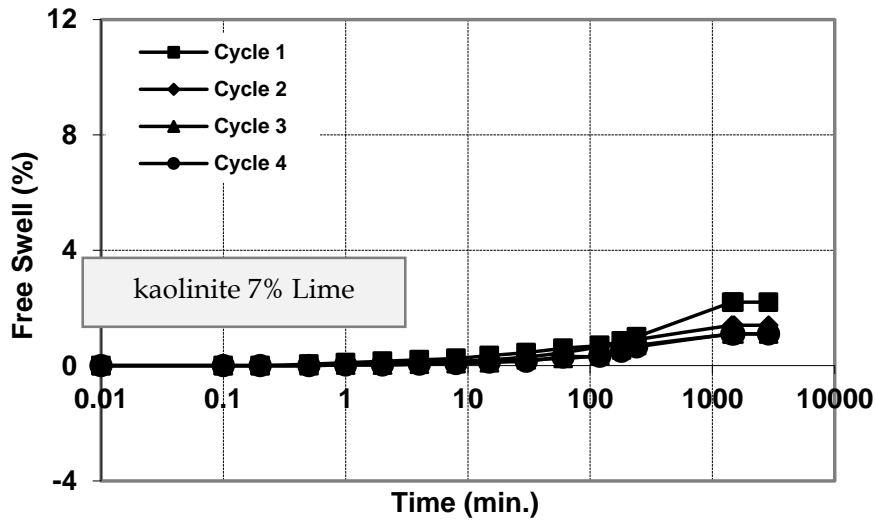

Fig (5) : Free swell potential of soil samples with time Further that, the cracks were propagated in soil samples during the wet-dry cycles; especially for bentonite soil. This behavior is attributed to that, In the kaolinite treated samples, the clay-lime reactions are certainly higher than the suction developed in these soils, which explains why no cracks were observed. Whereas the cracks propagation were obvious in the lime treated bentonite samples during wet-dry cycles. The increasing in free swell potential values and cracks propagation of the lime treated soil samples were attributed to the partial breakdown of cemented soil aggregates due to cyclic wetting and drying process. Further, it can be stated that the wet-dry cycles caused the gradual destruction of the pozzolanic reaction of lime treated soil samples.

\section{CONCLUSIONS}

Based on the test results, the following conclusions can be drawn:

1. The free swell potential of bentonite soil was greater than of kaolinite soil, which is apparently linked to the type and amount of clay mineral.

2. The test results indicate that beneficiary effect of lime stabilization is lost after cycling of wetting and drying of the expansive soils.

3.cyclic swelling process leads to gradual destruction of pozzolanic reaction of the lime-treated soil samples which lead to increase free swell potential.

4. Cracks propagation was more intensified in bentonite soil samples as compared with those of kaolinite soil during wet-dry cycles.

\section{REFERENCES}

1. Kodikara, J., Barbour, S. L. and Fredlund, D. G., "Change in Clay Structure and Behavior due to Wetting and Drying", Proceeding of the 8th Australian- New Zealand Conference on Geomechanics, Hobart Tasamia, PP. 179-196, 1999.

2. Abdullah, W. S., Alshibli, k. A. and Al-Zou ,bi, M. S., "Influence of Pore Water Chemistry on the Swelling behavior of Compacted Clays", Applied Clay Science, No. 15, pp. 447-462, 1999.

3. Afès, M., Didier, G., 2000. Stabilization of expansive soils: the case of clay in the area of Mila (Algeria). 
Bulletin of Engineering Geological Environment 59 (1), 75-83.

4. Akcanca f. and Aytekin M. (Effect of wettingdrying cycles on swelling behavior of lime stabilized sand-bentonite mixtures) Environ Earth Sci (2012) 66:67-74

5. Al-Mukhtar, M., Lasledj, A., Alcover, J.F., 2014. Lime consumption of different clayey soils. Appl. Clay Sci. 95, 133-145.

6. Al-Mukhtar,M., Khattab, S., Alcover, J.F., 2012. Microstructure and geotechnical properties of limetreated expansive clayey soil. Eng. Geol. 139-140, 1727.

7. Al-Mukhtar,M., Lasledj, A., Alcover, J.F., 2010. Behaviour and mineralogy changes in lime treated expansive soil at $20^{\circ} \mathrm{C}$. Appl. Clay Sci. 50, 191-198.

8. Alper, S., Gozde, I., Recep, Y.H., Kambiz, R., 2006. Utilisation of a very high lime fly ash for improvement of Izmir clay. Building and Environment 42 (2), 150155.

9. Al-Rawas, A.A., Hago, A.W., Al-Sarmi, H., 2005. Effect of lime, cement and Sarooj

10. (artificial pozzolan) on the swelling potential of an expansive soil from Oman.

11. Building and Environment 40 (5), 681-687.

12. Basma, A. A., Al-Homoud, A. S., Malkawi, A. I. H., and Al-Bashabsheh, M. A., " Swelling-Shrinkage Behavior of Natural Expansive Clays" , Applied Clay Science, No. 11, PP. 211-227, 1996.
13. Bell, F.G., 1996. Lime stabilization of clay minerals and soils. Eng. Geol. 42, 223-237.

14. Dasog, G. S., Acton, D. F., Mermut, A. R. and De Jong, E., "Shrink-Swell Potential and Cracking in Clay Soils of Saskatchewan", Canadian Soil Science Journal, Vol.68, PP. 251-260, 1988.

15. Day, R.W. "Swell-Shrink Behavior of Compacted Clay", Journal of Geotechnical Engg., ASCE, Vol.120,No.3, PP.618-623, 1994.

16. Guney Y, Sari D, Cetin M, Tuncan M (2007) Impact of cycling wetting-drying on swelling behavior of lime-stabilized soil. Build Environ 42(2):681-688.

17. Ingles, O.G., Metcalf, J.B., 1973. Soil Stabilization Principles and Practice. John Wiley \& Sons, New York. 18. Little, D.N., 1995. Handbook for Stabilization of Pavement Sub Grade and Base Courses with Lime. National Lime Association, Kendall Hunt Publishing Company, Iowa, USA.

19. Rao SM, Reddy BVV, Muttharam M (2001) Impact of cycling wetting and drying on the swelling behaviour of stabilized expansive soils. Eng Geol 60(34):221-233.

20. Yazdandoust, F., Yasrobi, S.S., 2010. Effect of cyclic wetting and drying swelling behavior of polymerstabilized expansive clays. Applied Clay Science 50, 461-468.

21. Zhang JR, Cao X (2002) Stabilization of expansive soil by lime and fly ash. Journal Wuhan University of Technology, Materials Science Edition, 17, 4, 73-77. 